\title{
A new method for the release of Amblyseius andersoni (Acari: Phytoseiidae) in young apple orchards
}

\author{
ÁRPÁD SZABÓ and BÉlA PÉNZES \\ Corvinus University of Budapest, Faculty of Horticultural Science, Department of Entomology, Budapest, Hungary; \\ e-mails: arpad.szabo@uni-corvinus.hu; bela.penzes@uni-corvinus.hu
}

Key words. Acari, Phytoseiidae, Amblyseius andersoni, mite release, apple, mite management

\begin{abstract}
The use of phytoseiid species in biological plant protection is widespread. However, the techniques used to release them differ. The possible release of Amblyseius andersoni (Chant, 1959) using a new method was tested. High numbers of this mite overwinter in the ground litter in Hungarian orchards. By transferring such ground litter to plots in young orchards, the population density was found to be significantly increased in the release compared to control plots; A. andersoni became the dominant phytoseiid species in the new orchard. Due to the rate at which it spreads, this species was also recorded in the control plots towards the end of the growing season (Aug., Sept.), at which time there was no significant difference in the numbers of this species in the treated and control plots. In the winter following release, A. andersoni was found in the ground litter of the orchard.
\end{abstract}

\section{INTRODUCTION}

In European apple orchards predatory mites belonging to the family Phytoseiidae are essential for the control of pest mites (Tetranychidae \& Eriophyidae) (Solomon et al., 2000). Amblyseius andersoni, a generalist phytoseiid species, is common in apple orchards in several countries (Croft, 1994; Duso \& Pasini, 2003).

The predatory mite population in Hungarian apple orchards, which occupy an area of 41,000 ha, is poorly investigated. According to Komlovszky \& Jenser (1987) and Hegyi et al. (2003), the most common phytoseiid species are Euseius finlandicus and Amblyseius andersoni. The role of the latter in controlling phytophagous mites is not evident yet. A. andersoni can keep the population of the two-spotted spider mite under the economic threshold level in certain cases (Duso, 1992; Duso \& Pasini, 2003). However, in others it does not increase in abundance with that of the pest (Duso \& Vettorazzo, 1999) and other phytoseiid species are the dominant predators (Duso, 1989). The ability of $A$. andersoni to control pest populations depends on several factors, such as the climatic conditions in the area (Croft et al., 1993), the morphological characteristics of plant leaves (Duso \& Vettorazzo, 1999), inter-specific competition (Duso, 1989) and last but not least, the use of pesticides (Duso et al., 1992; Pozzebon et al., 2002).

From the viewpoint of the biological control of pest mites the knowledge of where phytoseiids overwinter is undoubtedly important (Veerman, 1992). There is some information on this. Authors most often mention crevices and cracks in the trunks on older parts of trees as places for overwintering (Chant, 1959; Overmeer, 1985; Duso, 1989; Zacharda, 1989). However, there are many reports of phytoseiid species overwintering in ground litter, fallen leaves and dried weeds (McGroarty \& Croft, 1978; Raworth et al., 1994). According to Putman (1959),
Typhlodromus pyri overwinters in trunk crevices, $A$. andersoni on the trees and in ground litter, whereas $A$. cucumeris mainly in ground litter and soil. In apple orchards in Michigan, A. fallacis overwinters in ground litter and is present in the undergrowth all year round (McGroarty \& Croft, 1978) whereas Broufas et al. (2002) did not find E. finlandicus in the ground litter in peach orchards and do not regard it as an important overwintering site. Experiments carried out in Hungary confirm E. finlandicus, T. pyri and A. andersoni overwinter in ground litter (Szabó \& Pénzes, 2007). Overwintering sites might be important in determining the effectiveness of predatory mites as biological control agents in productive orchards; probably due to the low number of overwintering places on healthy trees predators do not become sufficiently abundant before the end of summer (Chant, 1959). Raworth et al. (1994) proved using herbaceous test plants that Neoseiulus californicus does not only overwinter in the ground litter, but migrates from there to the canopy in spring. Similarly, Amblyseius fallacis, which is primarily adapted to living on plants at ground level, migrates up into the canopy of trees in early summer if the food source on the herbaceous plants is depleted (Johnson \& Croft, 1981).

There are several studies on phytoseiid mites that mention methods of releasing these mites for research purposes some of which have been adapted for horticultural practices. During the vegetation period, active forms of phytoseiid mites infesting the green parts of plants are used to introduce these mites into crops. Easterbrook (1992) successfully released T. pyri on one-year-old apple shoots into strawberry field, whereas Zacharda \& Hluchy (1997) used one-year-old grapevines. Also for research purposes, Croft \& Macrae (1992) and Marshall \& Lester (2001) successfully released predatory mites simply by placing green leaves infested with the mites on the target 
trees. It is also popular to release dormant mites during the overwintering period, because this can be done using the woody older parts of plants, which provide overwintering places for the predatory mites. T. pyri and Kampimodromus aberrans can be released in this way using two-year-old woody parts of plants in February (Duso \& Vettorazzo, 1999). In apple orchards in Poland, it is common to place textile strips on trees colonized by $T$. pyri between July and August, and then in winter to remove the strips and place them in new orchards. Moreover, releasing overwintering specimens on branches is also possible (Sekrecka \& Niemczyk, 2006). In Hungary, textile strips are also used to introduce $T$. pyri into vineyards in the Sopron wine region (Molnár \& Májer, 1999).

The aim of this study was to determine whether it is possible to transfer $A$. andersoni from old to young apple orchards by transferring ground litter from old to young apple orchards. It is assumed that this species has the same spatial and seasonal distributions as $A$. fallacis (Johnson \& Croft, 1981) and N. californicus (Raworth et al., 1994). These mites overwinter in the ground litter, migrate up into the canopy during the growing season and in autumn migrate back down to ground level. We hypothesize that if $A$. andersoni behaves similarly, specimens that overwinter in the ground litter can be transported in this medium during the dormancy period and released in other orchards. Furthermore, this method could also be used for releasing other phytoseiid mites in other types of orchards.

\section{MATERIAL AND METHODS}

\section{Study location}

Our studies were carried out in a three-year old apple orchard of Golden Reinders variety at the Experimental Station of Corvinus University of Budapest in 2008, and repeated in 2009 (Pest County, Soroksár, altitude: $109 \mathrm{~m}$, latitude $47^{\circ} 23^{\prime} 52.3^{\prime \prime} \mathrm{N}$, longitude $\left.19^{\circ} 08^{\prime} 53.5^{\prime \prime} \mathrm{E}\right)$. The soil in the orchard is sandy, between rows of trees the ground is covered with grass, which is regularly mown, whereas ground in which the rows of trees are planted is treated with herbicides (glyphosate isopropylamine salt) and was weed-free at the time of our experiments. The trees were drip irrigated. The orchard spreads over 3.2 ha, the spacing is $3.6 \mathrm{~m} \times 1.2 \mathrm{~m}$; with M9 rootstock. IPM was applied against pests. In the vegetation period, thiacloprid, thiamethoxam and indoxacarb were applied, as well as pesticides with tebuconazole, dithianon, kresoxim-methyl, triadimenol, folpet and captan as the active agents.

In 2008, the ground litter used for the release of mites was collected from a ten-year-old apple orchard (Fejér County, Tordas, altitude: $173 \mathrm{~m}$, latitude $47^{\circ} 21^{\prime} 43.1^{\prime \prime} \mathrm{N}$, longitude $\left.18^{\circ} 46^{\prime} 52.6^{\prime \prime} \mathrm{E}\right)$, where based on our previous studies Amblyseius andersoni was the dominant phytoseiid species. In the second experimental year (2009), the ground litter for the release was collected from the orchard in which the mites were released in 2008 because our release method seemed to be highly effective. The ground litter with females of $A$. andersoni was placed in the test orchard on 11 March 2008 and 3 March 2009.

\section{Methods, identification}

A Berlese-Tullgren funnel was used to extract mites from the litter. In the plots where A. andersoni was released, 21 of ground litter in a small mesh-size net bag was attached to the tree trunks. The ground litter contained approx. 25 overwintering A. andersoni females in 2008 and 44 in 2009.

In the growing season leaves were collected and stored in cold conditions for a maximum of four days. The undersides of these leaves were examined under a stereo-microscope. The mobile individuals of phytoseiid mites were collected and placed in Berlese-Hoyer's medium, and the number of eggs recorded. The mobile individuals of species belonging to other families (Stigmaeidae, Tydeidae, and Tetranychidae) were also counted. In order to count apple rust mites, not the whole leaf surface but an area of leaf of $28 \mathrm{~mm}^{2}$ (the area visible at $40 \times$ magnification) was examined. The position of this area on a leaf was chosen at random. Phytoseiid species were identified using the keys of Wainstein (1972), Karg (1993) and Chant \& McMurtry (1994).

\section{Sampling and study design}

In 2008 , leaf samples were collected every two weeks during the growing season $(21 / 4 ; 5 / 5 ; 19 / 5 ; 2 / 6 ; 16 / 6 ; 30 / 6 ; 14 / 7 ; 4 / 8$; $18 / 8 ; 9 / 9)$. Nine adjacent trees were designated in each plot in 5 replicates, and 3 leaves per tree were examined (27 leaves/plot; 135 leaves per treatment). In 2009, we used a slightly modified sampling method. We collected 25 leaves per plot in 4 replicates (100 leaves per treatment) 9 times during the growing season $(20 / 4 ; 4 / 5 ; 18 / 5 ; 2 / 6 ; 15 / 6 ; 29 / 6 ; 13 / 7 ; 27 / 7 ; 24 / 8)$. The plots were always randomly assigned in the replicates. There were 12 metre buffer zones between the plots. There was one treatment and a control with no release.

During the dormancy period, following the release in 2008, the number of $A$. andersoni overwintering in the litter was also determined using a Berlese-Tullgren funnel. The number of phytoseiid mites present in 1 litre of litter collected from each (5) release plot was counted. During the growing season, the released mites also spread into the control plot adjacent to the release plots, thus it could not be used as a control for the dormancy period. As a result, new control plots were chosen far away from the release plots in the young orchard. The other parameters of the new control plots were the same, and they were used only for litter extraction.

\section{Data analysis}

Statistical analysis was carried out to compare the number of phytoseiid mites in the different treatments and on different sampling dates. As the data often did not conform to a normal distribution, all the abundances were compared using Welch's t-test after $\ln (\mathrm{x}+1)$ transformation of the data. The statistical analyses were carried out using the software package RopStat (A. Vargha, Budapest, Hungary).

\section{RESULTS}

\section{The population dynamics of prey species}

In 2008 (April, May), the population density of the apple rust mite was low at the beginning of the growing season (0.2-4.0 individuals / leaf surface). In June, after a slow increase the numbers increased substantially and peaked during this month (17.8 individuals / leaf unit). However, they caused no visible damage at this population density. The pesticide treatment (indoxacarb + triadimenol + folpet) applied on 20 June resulted in an unexpected effect; the population of apple rust mites rapidly declined $(<0.04$ individuals/leaf surface). After that and only during sampling in August were apple rust mites found again on young untreated leaves. Although the 

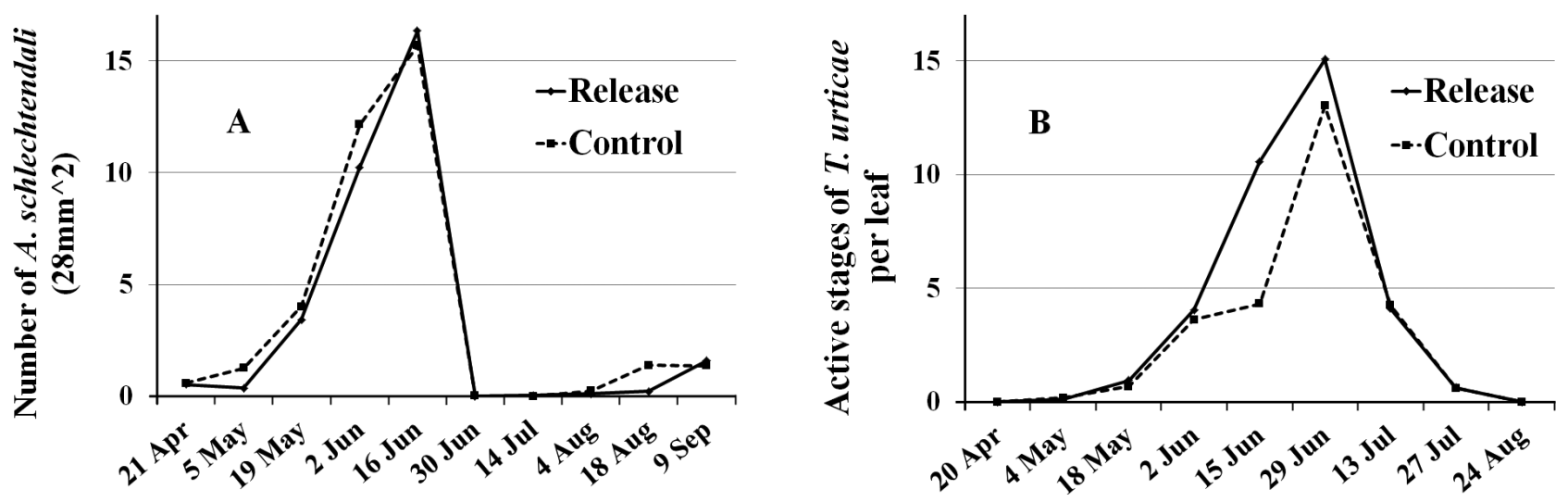

Fig. 1. Numbers of A. schlechtendali (A) (Soroksár, 2008) and T. urticae (B) (Soroksár, 2009) recorded in the release treatment and the control.

population started to increase again in September their numbers $(<3.6$ individuals/leaf surface $)$ were considerably less than those recorded in June (Fig. 1A). There were no significant differences in the numbers of $A$. schlechtendali recorded in the treatments. The twospotted spider mite (Tetranychus urticae) and red spider mite (Panonychus ulmi) occurred sporadically in all plots, sometimes not even reaching the economic threshold level as in 2008, thus no statistical analysis was necessary.

In the second year (2009), the most abundant mite pest was the two spotted spider mite. Its population increased up until June and then declined naturally as pesticides were not applied. There was no significant difference between the number of this mite in the release treatment and control (Fig. 1B.). The dominant phytoseiid species, as in 2008, was $A$. andersoni.

\section{The effect of the bags of ground litter attached to tree trunks}

In the release treatment specimens of $A$. andersoni were collected at each sampling periods except the first in 2008 (Fig. 2). In samples collected in April and May, the number of individuals per leaf in the released treatment was low $(<0.03$ individuals/leaf) and did not differing significantly from that in the control $(05 / 5, \mathrm{p}=0.14 ; 19 / 5$, $\mathrm{p}=0.37)$. From 2 June until 4 August, the numbers of $A$. andersoni recorded in the release treatment was significantly higher than in the control treatment $(02 / 6, \mathrm{p}=0.02$; $16 / 6, \mathrm{p}=0.0003 ; 30 / 6, \mathrm{p}=0.0001 ; 14 / 7, \mathrm{p}=0.00001$; $04 / 8, p=0.002)$. In June, when there was a peak in the number of prey, the number of predators also peaked; the number of phytoseiid mites was highest at that time and

TABLE 1. The percentage composition of the phytoseiid mites recorded on the leaves in the release and control treatments in both experimental years (Soroksár, 2008, 2009).

\begin{tabular}{lccccc}
\hline \multirow{2}{*}{ Species (\%) } & \multicolumn{2}{c}{2008} & & \multicolumn{2}{c}{2009} \\
\cline { 2 - 3 } \cline { 6 - 7 } & Control & Release & & Control & Release \\
\hline A. andersoni & 44.8 & 87.4 & & 7.1 & 39.8 \\
E. finlandicus & 46.1 & 10.6 & & 88.7 & 55.1 \\
Other phytoseiids & 9.1 & 2.0 & & 4.2 & 5.1 \\
\hline
\end{tabular}

the first specimens of $A$. andersoni were recorded in the control treatment (0.04 individuals/leaf) (Fig. 2). After the disappearance of the prey, the number of phytoseiids also declined. In both treatments from July until the onset of overwintering, the population of predatory mites increased again and $A$. andersoni appeared in the control plot, but only at the end of the growing season in August and September (Fig. 2).

In the second growing season (2009) the population dynamics of $A$. andersoni in both treatments were similar to that recorded in the first year but it was considerably less abundant (Fig. 3). On 29 June and 13 July $A$. andersoni was significantly more abundant in the release treatment than in the control $(29 / 6, \mathrm{p}=0.03038 ; 13 / 7, \mathrm{p}=$ 0.03038). After pooling the data, the difference between treatments over a longer period (from 2 June until 13 July) is also significant ( $p=6.7 \mathrm{E}-06)$. At the end of the growing season mites of the same species as those released were recorded in the control as was the case in 2008, therefore there was no significant difference between the treatments (Fig. 3). The differences in the percentage composition of the phytoseiids in control and treated plots were similar to that recorded in 2008. $A$. andersoni made up a high percentage of the phytoseiid

TABLE 2. Number and percentage composition of phytoseiid mites recorded overwintering in the ground cover in the release and control plots in the $A$. andersoni release treatment (Soroksár, 2009).

\begin{tabular}{lcccccc}
\hline & \multicolumn{2}{c}{$\begin{array}{c}\text { A. andersoni- } \\
\text { release treatment }\end{array}$} & & \multicolumn{2}{c}{ Control } \\
\cline { 2 - 3 } \cline { 6 - 7 } & $\mathrm{n}$ & $\%$ & & $\mathrm{n}$ & $\%$ \\
\hline Phytoseiidae & 303 & 100.00 & & 360 & 100.00 \\
\hline Amblyseius andersoni & 52 & 17.16 & & 2 & 0.56 \\
Amblyseius agrestis & 240 & 79.21 & & 353 & 98.06 \\
Neoseiulus sp. & 10 & 3.30 & & 0 & 0.00 \\
Amblyseius meridionalis & 1 & 0.33 & & 0.56 \\
Amblyseius lutezhicus & 0 & 0.00 & & 0.56 \\
Anthoseius pirianykae & 0 & 0.00 & & 1 & 0.28 \\
\hline
\end{tabular}




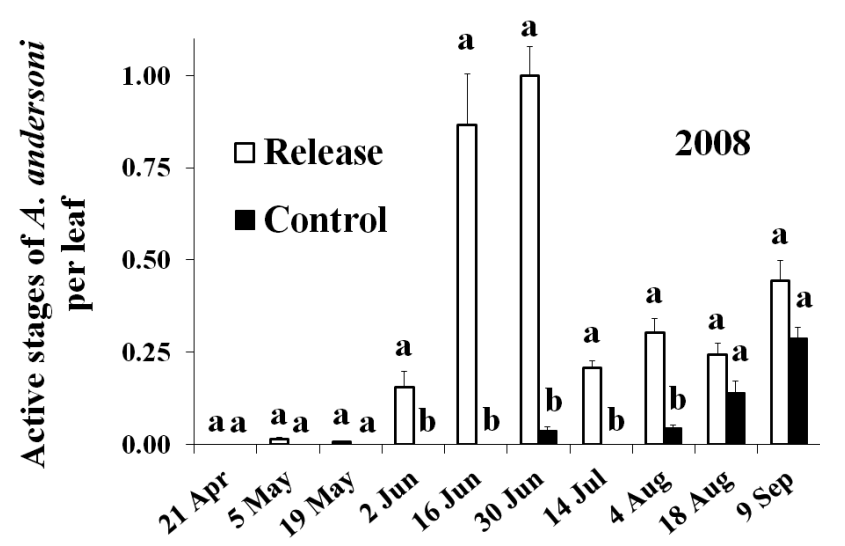

Fig. 2. Numbers of $A$. andersoni recorded per leaf in the release treatment and control (Soroksár, 2008). The columns for each date sampled labelled with different letters are significantly different at $\mathrm{p}<0.05$. Data were transformed using $\ln (\mathrm{x}+1)$

composition. The percentage of E. finlandicus declined but it did not become extinct ( $\mathrm{p}=0.8888)$ (Table 1$)$.

During the two growing seasons, in the release treatment and the control, altogether nine species of mites were collected from leaves $(A$. andersoni, E. finlandicus, T. pyri, Anthoseius pirianykae, Amblyseius agrestis, Neoseiulus cucumeris, K. aberrans, Dubininellus sp. and Paraseiulus triporus) and the finding of A. pirianykae (Wainstein, 1972) was the first record for this species for Hungary.

\section{The composition of Phytoseiidae recorded in the ground litter in the winter following release}

In the winter following the release of $A$. andersoni $(08 / 1,2009)$, specimens of six species of phytoseiid were extracted from litter (Table 2). $98.06 \%$ of the species identified belonged to Amblyseius (Neoseiulus) agrestis, with the other species occurring only sporadically. $A$. agrestis was also the dominant species in the release treatment $(79.21 \%)$. In terms of the number of $A$. andersoni there was a significant $(\mathrm{p}=0.002)$ difference between the treatments. The percentage of this species recorded in the release treatment was $17.16 \%$, whereas in the control it was only $0.56 \%$ (Table 2 ). Some rare species (T. pyri, A. agrestis, N. cucumeris, K. aberrans, Dubininellus sp. and P. triporus) that were collected from the foliage in the growing season were not found in the ground litter during the dormancy period.

\section{DISCUSSION}

During the growing seasons following the release of mites in ground litter, the number of $A$. andersoni per leaf was significantly higher in the release treatment than in the control in both years. These results indicate that (1) $A$. andersoni migrates from ground litter up into the foliage of trees in search of prey and (2) ground litter is an appropriate medium for releasing mites in apple orchards. In accordance with the findings of Raworth et al. (1994), we suppose that the mites reach the foliage by moving up the trunks of the trees to which the net bags of litter were

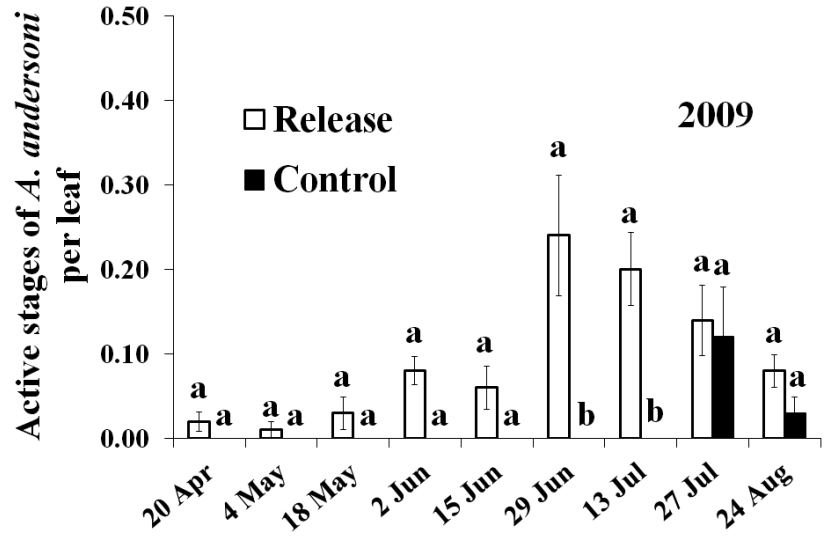

Fig. 3. Numbers of $A$. andersoni recorded per leaf in the release treatment and control (Soroksár, 2009). The columns for each period sampled labelled with different letters are significantly different at $\mathrm{p}<0.05$. Data were transformed using $\ln (\mathrm{x}+1)$.

attached. Although in the release treatment this mite was already the dominant species at the beginning of the growing seasons, it did not significantly affect the numbers of E. finlandicus, which was more abundant in the control than A. andersoni.

In the presence of $Z$. mali, it is difficult for some phytoseiid species ( $T$. pyri) to colonize trees, whereas for other species (A. andersoni) it does not pose a problem (Croft, 1994), which is confirmed by our results. Although the numbers of $A$. andersoni declined after the depletion of the primary prey in 2008 , this species remained dominant in the treated plots. The continued survival of this species there was probably due to the availability of alternative food sources (Ivancich Gambaro, 1988). Stress caused by the lack of food causes phytoseiid mites to disperse (Croft et al., 1995; Schausberger \& Croft, 1999), which is probably an important factor in the rapid spread of $A$. andersoni. This phenomenon was most marked in August and September, in both years. By the end of both growing seasons the released species spread evenly throughout the test plots and as a result there was significant difference between the treatments.

During dormancy following the release, Amblyseius (Neoseiulus) agrestis overwintered in high numbers in the ground litter. However, it was recorded on the foliage only once throughout the whole sampling period, so it is closely connected with ground litter. This is also characteristic of Amblyseius meridionalis and Amblyseius lutezhicus. The number of $A$. andersoni females overwintering in the ground litter of release plots was significantly higher than in the control plots. It is assumed that they migrated from the foliage of young trees, where suitable places for overwintering are scarce, to the litter on the ground via the trunk. Ground litter containing $A$. andersoni can be used again for releasing this mite in other orchards. According to our study, the spatial and seasonal distribution of A. fallacis and N. californicus in orchards (Johnson \& Croft, 1981; Raworth et al., 1994) is similar to that of $A$. andersoni, thus their release using ground litter is also possible. 
In our opinion, this new, simple and rapid method of release can also be successfully used to release mites in other horticultural crops (rose, strawberry, etc.), as well as to release other phytoseiid species, which stay on the foliage during the growing season but overwinter in ground litter.

ACKNOWLEDGEMENTS. I am grateful to S. Kreiter for his invaluable help with the identification of the Anthoseius specimens. The present research was partially supported by grant TÁMOP 4.2.1.B-09/1/KMR-2010-0005 and TÁMOP 4.2.2/ B-10/1-2010-0023.

\section{REFERENCES}

Broufas G.D., Koveos D.S. \& Georgatsis D.I. 2002: Overwintering sites and winter mortality of Euseius finlandicus (Acari: Phytoseiidae) in a peach orchard in northern Greece. - Exp. Appl. Acarol. 26: 1-12.

Chant D.A. 1959: Phytoseiid mites (Acarina: Phytoseiidae). Part I. Bionomics of seven species in southeastern England. - Can. Entomol. 12: 5-44.

Chant D.A. \& McMurtry J.A. 1994: A review of the subfamilies Phytoseiinae and Typhlodrominae (Acari: Phytoseiidae). - Int. J. Acarol. 20: 223-316.

Croft B.A. 1994: Biological control of apple mites by a phytoseiid mite complex and Zetzellia mali (Acari: Stigmaeidae): long-term effects and impact of azinphosmethyl on colonization by Amblyseius andersoni (Acari: Phytoseiidae). - Environ. Entomol. 23: 1317-1325.

Croft B.A. \& MacRae I.V. 1992: Biological control of apple mites by mixed populations of Metaseiulus occidentalis (Nesbitt) and Typhlodromus pyri Scheuten (Acari: Phytoseiidae). - Environ. Entomol. 22: 865-873.

Croft B.A., Messing R.H., Dunley J.E. \& Strong W.B. 1993: Effects of humidity on eggs and immatures of Neoseiulus fallacis, Amblyseius andersoni, Metaseiulus occidentalis and Typhlodromus pyri (Phytoseiidae): implications for biological control on apple, caneberry, strawberry and hop. - Exp. Appl. Acarol. 17: 451-459.

Croft B.A., Kim S.S. \& Kim D.I. 1995: Leaf residency and interleaf movement of four phytoseiid mites (Acari: Phytoseiidae) on apple. - Environ. Entomol. 24: 1344-1351.

Duso C. 1989: Role of the predatory mites Amblyseius aberrans (Oud.), Typhlodromus pyri Scheuten and Amblyseius andersoni (Chant) (Acari, Phytoseiidae) in vineyards. I. The effect of single or mixed phytoseiid population releases on spider mite densities (Acari, Tetranychidae). - J. Appl. Entomol. 107: 474-492.

Duso C. 1992: Biological control of tetranychid mites in peach orchards of northern Italy: Role of Amblyseius finlandicus (Oud.) (Acari: Phytoseiidae). - Acta Phytopathol. Entomol. Hungar. 27: 211-217.

Duso C. \& PAsinI M. 2003: Distribution of the predatory mite Amblyseius andersoni (Acari: Phytoseiidae) on different apple cultivars. - Anz. Schädlingsk. - J. Pest Sci. 76: 33-40.

Duso C. \& Vettorazzo E. 1999: Mite population dynamics on different grape varieties with or without phytoseiids released (Acari: Phytoseiidae). - Exp. Appl. Acarol. 23: 741-763.

Duso C., Camporese P. \& Van Der Geest L.P.S. 1992: Toxicity of a number of pesticides to strains of Typhlodromus pyri and Amblyseius andersoni (Acari: Phytoseiidae). — Entomophaga 37: 363-372.

EASTERBROOK M.A. 1992: The possibilities for control of twospotted spider mite Tetranychus urticae on field-grown straw- berries in the UK by predatory mites. - Biocontr. Sci. Technol. 2: 235-245.

Hegyi T., Molnár J. \& Földes L.Sz. 2003: Ragadozóatkák dominancia-viszonyai Szabolcs-Szatmár-Bereg megye almaültetvényeiben. [The species of predatory mites in apple orchards in the County of Szabolcs-Szatmár-Bereg.] — Kertgazdaság 35: 5-9 [in Hungarian, English abstr.].

Ivancich Gambaro P. 1988: Natural alternative food for Amblyseius andersoni Chant (Acarina: Phytoseiidae) on plants without prey. - Redia 71: 161-171.

Johnson D.T. \& CROFT B.A. 1981: Dispersal of Amblyseius fallacis (Acarina: Phytoseiidae) in apple ecosystem. - Environ. Entomol. 10: 313-319.

KARG W. 1993: Phytoseioidea. In Karg W. (ed.): Raubmilben (Die Tierwelt Deutschlands). Gustav Fischer, Jena, pp. 170-254.

Komlovszky Sz.I. \& Jenser G. 1987: The frequent occurrence of the predatory mites Amblyseius finlandicus Oudemans and Phytoseius plumifer Canestrini et Fanzago on fruit trees. Növényvédelem 23: 193-201 [in Hungarian, English abstr.].

Marshall D.B. \& Lester P.J. 2001: The transfer of Typhlodromus pyri on grape leaves for biological control of Panonychus ulmi (Acari: Phytoseiidae, Tetranychidae) in vineyards in Ontario, Canada. - Biol. Contr. 20: 228-235.

McGroartry D.L. \& Croft B.A. 1978: Sampling the density and distribution of Amblyseius fallacis (Acarina: Phytoseiidae) in the ground cover of Michigan apple orchards. - Can. Entomol. 110: 785-794.

MolnÁr Gy.J. \& MÁJER J. 1999: The release of predatory mites into vineyards of Badacsony. — Kertészet és Szõlészet 48: 26-28 [in Hungarian].

OvermeER W.P.J. 1985: Diapause. In Helle W. \& Sabelis M.W. (eds): Spider Mites, their Biology, Natural Enemies and Control. Vol. 1b. Elsevier, Amsterdam, Oxford, New York, Tokyo, pp. 95-102.

Pozzebon A., Duso C. \& Pavanetto E. 2002: Side effects of some fungicides on phytoseiid mites (Acari, Phytoseiidae) in north-Italian vineyards. - J. Pest Sci. 5: 132-136.

Putman W.L. 1959: Hibernation sites of phytoseiids (Acarina: Phytoseiidae) in Ontario peach orchards. - Can. Entomol. 91: 735-741.

Raworth D.A., Fauvel G. \& Auger P. 1994: Location, reproduction and movement of Neoseiulus californicus (Acari: Phytoseiidae) during the autumn, winter and spring in orchards in the south of France. - Exp. Appl. Acarol. 18: 593-602.

Schausberger P. \& Croft B.A. 1999: Activity, feeding, and development among larvae of specialist and generalist phytoseiid mite species (Acari: Phytoseiidae). - Environ. Entomol. 28: 322-329.

SeKRecka M. \& NiemczYK E. 2006: Introducing Typhlodromus pyri (Phytoseiidae) into apple orchards in Poland. - J. Fruit Ornam. Plant Res. 14: 203-207.

Solomon M.G., Cross J.V., Fitz Gerald J.D., Campbell C., Jolly R.L., Olszak R.W., NiemczyK E. \& Vogt H. 2000: Biocontrol of pests of apples and pears in northern and central Europe - 3. Predators. - Biocontr. Sci. Technol. 10: 91-128.

SzABÓ Á. \& PÉNZes B. 2007: Overwintering predatory mites in apple orchard. 28. In: Integrált termesztés a kertészeti és szántóföldi kultúrákban, 27. november 2007. [Proc. Conference of Integrated Plant Production in Horticultural and Arable Crops, 27 November 2007.] Mezõgazdasági Szakigazgatási Hivatal Központ, Növény-, Talaj- és Agrárkörnyezet-védelmi Igazgatóság, Budapest, pp. 57-60. [in Hungarian]. 
VeErman A. 1992: Diapause in phytoseiid mites: a review. Exp. Appl. Acarol. 14: 1-60.

Wainstein B.A. 1972: New species of the family Phytoseiidae (Parasitiformes). - Zool. Zh. 51: 1407-1411 [in Russian].

ZACHARDA M. 1989: Seasonal history of Typhlodromus pyri (Acari: Mesostigmata: Phytoseiidae) in a commercial apple orchard in Czechoslovakia. - Exp. Appl. Acarol. 6: 307-325.
ZaChARDA M. \& HLUChÝ M. 1997: Biological control of the two-spotted spider mite Tetranychus urticae on strawberries by the predatory phytoseiid mite Typhlodromus pyri (Acari, Tetranychidae, Phytoseiidae). — Exp. Appl. Acarol. 20: 83-94.

Received August 13, 2012; revised and accepted January 21, 2013 